\title{
Voices of Indonesian Migrant Workers at Home and Abroad
}

\author{
Howard Lorne Martyn ${ }^{1}$ \\ ${ }^{1}$ Guangdong University of Foreign Studies, Guangzhou, Guangdong, People's Republic of China \\ Correspondence: Howard Lorne Martyn. E-mail: howardeap@gmail.com
}

Received: June 1, 2018 Accepted: June 19, $2018 \quad$ Online Published: July 27, 2018

doi:10.5539/ass.v14n8p119

URL: https://doi.org/10.5539/ass.v14n8p119

\begin{abstract}
In this paper I discuss interviews conducted with Indonesian village women, concerning their decisions to sojourn abroad for work. The women detail three factors that they believe compel them to seek work abroad: lack of job opportunities, lack of educational and training opportunities and personal desire to experience life outside the confines of family and village life. They also raise the issue of government biases in educational and vocational planning that negatively affects villagers' abilities to find employment within Indonesia, and particularly within rural environments.

I also interviewed community support workers who mention political patronage as a factor in allocating funds for educational and training projects. Recent studies indicate that the Indonesian government has, for many years, prioritized formal education at the public-school level in urban centers and larger provincial towns, but that poorer rural villages lack access to similar opportunities. Many Indonesian women working in laboring positions abroad emanate from these poorer villages.

Participant recommendations include delinking village educational funding from political patronage, and allocating more funds to remote villages, not only in terms of building more primary and secondary schools but also in terms of providing long-term vocational training, particularly for young adults, which, in combination with increased employment opportunities, may decrease the necessity to migrate.
\end{abstract}

Data was collected through interviews and written journals in Indonesia and Hong Kong between 2005 and 2017.

Keywords: domestic labor, Indonesia, narrative research, village education, vocational education, women migrants

\section{Introduction}

This paper examines self-reported factors that Indonesian migrant participants believe compels them to leave their rural villages to work abroad. It focuses on two groups of migrant women: those who have returned and are considering another sojourn abroad - interviews were conducted in Banten province and Jakarta, Indonesia; and those who are working overseas - interviews and longer written narratives were undertaken in Hong Kong. Interviews were also conducted with migrant rights activists who situated the contested nature of labor migration within the political economy. This paper begins by discussing the recent historical background concerning government decisions which have adversely affected rural villagers. It goes on to discuss how migrants believe these decisions have impacted them. It then calls for changes in the allocation of educational financing to rural districts. And finally this paper suggests that the government regularize informal work and empower independent workers associations to monitor employer controlled factors such as hourly pay, overtime pay, statutory leave, and issues relating to workers health, particularly dangerous or unhealthy work environments, that threaten the wellbeing of employees.

\subsection{Recent Historical Background}

The dramatic increase in migration from rural to urban Indonesia and from Indonesia to neighboring countries and territories since the late 1990's, has its roots in economic and political development. At the start of 1997, Indonesia's economy appeared to be in good condition with approximately $8 \%$ growth and a stable inflation rate of less than $10 \%$. The apparently stable economy largely contributed to Suharto's election win. In May of 1997 Suharto's Golkar Party had its best ever election results, capturing $74.5 \%$ of votes, an increase of $6.5 \%$ over the previous national election (Van Dijk, 2001).

Although Indonesia has pursued a policy of economic deregulation and privatization since Suharto's first 
national government in the 1960's, this has escalated since 1986, particularly in the power and natural resources sectors. This policy appeared to have bolstered the economy to the extent that, in 1996, Suharto talked of deregulation and privatization as the Golkar Party's recipe for sustained growth and a rise in living standards (Roy, 1997). It was believed that the increasing number of factories, (many with large foreign investments), would employ workers at gradually rising wages, thus solving the unemployment problem, and bringing much needed foreign capital into the country. This combination of privatization and deregulation appeared to be leading the way towards increasing manufacturing exports, employment and wealth.

However, the optimism of the early 1990's was dramatically shattered when in September 1997 the Asian economic crisis impacted on Indonesia and the economy collapsed. This, in turn, led to the Suharto government's financial crisis and a desperate need to generate foreign currency; a need which could partly be met through increased labor migration and remittances.

This economic crisis led to widespread opposition by workers and peasants to the culturally and politically repressive 'New Order' regime which Suharto had initiated in the mid-1960's during his first term in office. Citizens demanded not only a change of government but also a move towards a less repressive, more accountable system that would anticipate and prevent dramatic upheavals in interest rates and unemployment.

In sharp contrast to the growth of the early 1990's, in 1997, the economic growth was just $4.7 \%$, and plummeted to $-13.6 \%$ in 1998. Perhaps most significantly, the inflation rate went from $6.6 \%$ in 1996 to $77.6 \%$ in 1998 . With uncontrolled inflation, those living in cities were unable to purchase enough food for family needs, and to sustain the living standards established in the previous years of high growth. As bank deposits shrank in actual worth, there was a mass movement of account holders attempting to empty their accounts. In response the government closed 16 banks, without warning, on November 1, 1997. People panicked, and nationwide protests erupted. Hill (1999) and Tambunan (1998) argue that these interconnected events led to an economic meltdown and, within a year, the collapse of the Suharto government. Hill (1999) asserts that a prime error was made in assuming that exports had unlimited expansion potential. These false visions of the future economy led the largest corporations to become heavily indebted to overseas investors at unfavorable interest rates. When growth slowed, foreign investors withdrew their money, leaving the Indonesian Central Bank unable to maintain the rupiah exchange rate. It had no choice but to depreciate the currency (by $400 \%$ ) over the period of a few weeks. This left Indonesian businesses that had lost their foreign investors in an untenable position since their foreign debts had, in effect, risen by the depreciated percentage. Tambunan (1998) argues that lax controls exerted by the Central Bank allowed rapidly expanding businesses to accumulate too many short term foreign debts. He believes the crisis could have been averted had short term foreign currency loans (approximately US \$40 billion) been repayable over a longer period.

Economic collapse was accompanied by widespread social unrest throughout the country, led primarily by those who had lost their jobs and by university students who feared a future of unemployment and poverty. Rioting resulted in numerous deaths. Perhaps the worst single incident occurred at Jakarta's Trisakti University, on May 12, 1998 when police resorted to live ammunition, killing four students and wounding dozens. The level of civil unrest and violence drew worldwide attention from the ' $\mathrm{G} 7$ ' countries, each issuing statements condemning the death and destruction.

Social indicators all pointed to a country undergoing a major decline in the health and welfare of its population. By September 1998 the number of people living below the poverty line had reached 79.4 million, or 39 percent of the total population. This was worse than in any year since 1976. The National Family Planning Board (as cited in Van Dijk, 2001, p. 292) estimated that 40 million were "too poor to afford sufficient food of good quality" and that the number of malnourished children under the age of 5 had risen from $5 \%$ to $9 \%$. "Children had begun to die from malnourishment" (Van Dijk, pp. 292-293). Although the government, in cooperation with the International Monetary Fund had established a 'Social Safety Net' in July 1998, intending to provide milk, rice, and other staples at subsidized prices, it was viewed as too little too late.

In an attempt to relieve the situation, Indonesia borrowed heavily, becoming reliant on foreign aid and International Monetary Fund loans which had increased to US $\$ 65$ billion by June 1999. In a partial attempt to negotiate debt for equity swaps with foreign creditors, the transitional Habibie government allowed "foreign companies to establish holding companies or to acquire a one hundred percent stake in domestic ones" (Van Dijk, 2001, p. 298), thereby increasing capital investment, which was also encouraged with additional promises of cheap labor, primary production materials, and tax incentives.

Under these harsh economic conditions, it became necessary for both local and foreign factory owners to reduce costs. The manufacturing sectors in which women were the predominant workers, the textile $(56 \%)$, garment 
(82\%) and footwear (79\%) (TGF) industries continued to operate, but with massive lay-offs. For example, $67 \%$ of TGF workers in West Java were laid off in 1999, (Tjandraningsih, 2000). Workers who remained and had previously endured "long working hours, low wages, poor standards of health and poor safety" (Tjandraningsih, 2000 , p. 260) were forced into an even worse position. The income of contract workers, relative to inflation, was dramatically reduced. A typical $15 \%$ increase in factory salaries in 1999, was insignificant compared to the inflation rate which at that time had reached $100 \%$ (Tjandraningsih, 2000). Apart from this, non-compliance with government-set minimum wages, and a tendency to pay women workers an average of $22 \%$ less than their male counterparts, brought further hardships to the vast majority of workers. Furthermore, working hours in the late 1990 's had increased to " 12 hours or more", with factory owners "refusing to comply with the governments regulations on overtime rates" (Tjandraningsih, 2000, p. 263). Even relatively minor benefits were curtailed, for example, factories stopped stocking even rudimentary health care supplies, such as bandages and anti-bacterial disinfectants used to ward off infections due to everyday cuts. Subsidized factory-provided meals were largely discontinued, with workers having to pay inflated shop prices.

Due to a rise in the general unemployment rate and a lack of suitable employment for high school graduates, there was a tendency for factory owners to require a higher level of education for employees. High school graduation became a standard requirement for factory work, while those with less education were pushed out into whatever itinerant jobs they could find.

Many believe that the government privatization policy was forcing people to find alternate ways of earning a living by making even basic necessities unavailable at reasonable cost. Privatization and debt for equity swaps not only increased but moved into the previously sacrosanct areas of public services, welfare, and health services. Government divestitures were subsequently extended to public utilities, with the privatization of water utilities perhaps being the most contentious. Although government enterprises were criticized for being poorly managed, it was perhaps a breach of social contract for the government to put life sustaining substances into private hands. In 1998 the government sold water utilities in Jakarta, and irrigation facilities in rural areas. This led to massive protests by peasants, ecology groups, and the urban and rural poor (Friends of the Earth, 2007). But the proposed positioning of public utilities, and in particular water utilities, as "negotiable frontier-market businesses" (Citizens' Network on Essential Services, 2003, p. 87) had been commented upon as early as the mid-1990s in a World Bank report which noted that on average privately produced power is " 43 times more expensive than the average price charged by the public utility" (World Bank, 1995, p. 32). Nevertheless, the utility transfer went ahead.

Under private ownership, costs rose leading to a decline in the health and education of those who had previously been just marginally able to remain above the poverty line. These included children, the elderly, the physically and mentally infirm, and women. Resolutions to the catastrophe were sought by those affected and these included an increase in child labor (Harrison \& Scorse, 2003), transnational prostitution (Amin, 2003a, 2003b), a rapid rise in youth crimes and suicides (especially of the elderly) (Battistella \& Asis, 1999), and a dramatic increase in labor migration (Young, 2004).

It has been argued by Kessler (2003) that the sell-off of industries and services to foreign interests as part of the world-wide economic trend of economic liberalization or 'neoliberalism' has resulted in "sustained economic loss for developing economies [and]. . . catastrophic poverty for those who were already economically marginalized" (p. 5). Participants believe that the events described above indicate a government which is unconcerned with the welfare of the majority of Indonesians, due to their relative powerlessness. As discussed by participants below, this chain of events, continues to affect workers, the unemployed, women, villagers and those in remote rural areas, and as a result often feel compelled to seek work abroad.

\section{Method}

I employ a social-constructivist, narrative approach in data collection. Social-constructivist methods are, largely, attempts to avoid binary dichotomies that often occur in positivist statistical research. Social-constructivism, and in particular narrative methodologies, put human voices to the numbers; we imagine a face, rather than see a statistic. A 'snowball' method of contacting participants was utilized.

My personal experience with narratives began decades ago when working for a government correctional unit in Canada. I was required to interview those convicted of crimes - many violent, their families, victims, the police and other stakeholders, in consideration of possible supervised early release. Prior to interviews I would be given factual details, but what I did not know were the impacts of the event on the lives of individuals; impacts that could only be assessed through many hours of interviewing and discussion, held over multiple sessions in prisons, police stations, homes and offices. The findings contained in these narratives indicated complex 
situations that were usually not obvious when examined solely through the institutional lens of court documents, police reports, and statistical reports; hidden, more subtle motivations and consequences only came to light after in-depth interviewing in which the stakeholders could tell their stories.

Narrative data collection is the method of choice when the interviews may take a turn into the unknown; when the participant needs, for their own emotional well-being, to control direction, to say what needs, for them, to be said. The researcher needs to allow the participant to control - to provide a situation in which empowerment becomes a possibility - during the interview, certainly, but with the possibility of regaining control in the long term, under situations where control may be viewed as hopeful, at best. Under what situations is narrative research the optimum choice? Riesmann (2015), and Morris (2017) provide participants with the narrative freedom to discuss their end of life experiences while in the midst of severe illness, Bury (2001) examines identity, experience and how individual accounts of illness are experienced within a bio-medical 'grand narrative' frame. Gray (2001) interviewed 32 adolescents with autism, and their parents, about strategies for coping in daily life. Clough $(2002,2004)$, and Murray $(2010)$ invoke narrative methodology and story-telling with teenagers and young adults suffering extreme familial or societally induced stress. Brante (2012) examines life stories of teachers involved in difficult work situations. González-López (2015) finds narrative methodology suited to psycho-therapy with individuals suffering extreme sexual abuse. Klots (2011) uses a narrative methodology in investigating immigrant lives in New York City. Benish-Weisman (2009) discussed immigrant trauma with 22 Russian migrants to Israel. Martyn (2018), uses a narrative approach in discussing social action planning from a transformative educational perspective with Indonesian migrants in Hong Kong. His results suggest that narratives can become a powerful tool in the discussion, and subsequent action, against hegemonic forces that threaten the wellbeing of migrants.

Denzin (1989) describes narrative data collection as:

Tales of events that are significant for the narrator and his or her audience. A narrative as a story has a plot, a beginning, a middle and an end. It has internal logic that makes sense to the narrator. A narrative relates events to a temporal, causal sequence (p. 37).

Although narratives may progress from a beginning to an end, structurally, the story itself may follow no particular timeline. Indeed, it may flow forward, reverse, digress, and lurch forward again, uneasily. The narratives in this paper have no ending - they describe lives that are in transition; but transition does not imply limbo. In fact, the participants are moving forward, making plans, preparing for their new lives. Polkinghorne (1995) believes that narratives reveal those who are "attempt[ing] to progress to a solution, clarification, or the unraveling of an incomplete situation" (p. 7).

My intention in this paper is to examine participant reported issues that led to the migration decision, as well as migrants' feelings of (dis)satisfaction with that decision. Data was gathered in rural areas in Banten province, between 2004 and 2017, as well as in Jakarta and Hong Kong. Migrant narratives are verbatim; changes are made only where clarification is essential.

\section{Inducements to Migrate}

Three inducements to migrate were identified by participants: firstly, lack of financially viable employment within Indonesia; secondly, lack of job skills training and adult education opportunities that might lead to better job possibilities; and thirdly, dissatisfaction with parochial family and village life, leading to a desire for wider life experiences. I was accompanied to villages in Banten province by Sheena ${ }^{1}$, an outreach advocate for Serikat Buruh Migran Indonesia (Indonesian Migrant Workers Union, or SBMI), based in Jakarta who lobbies for improved monitoring of the recruitment process, as well as improved training center programs, within Java. While in Banten I stayed in the home of the village secretary and his wife, Fendi and Hari (a returned migrant), and their young daughter, Mille.

\subsection{Lack of Financially Viable Employment}

Although inflation in Indonesia dropped in 2017 and the first quarter of 2018 (World Bank, 2018), this did not affect all areas of the country; rural areas saw a slight rise in the cost of basic foodstuffs, particularly in cereals and root crops, partly due to infestations, that largely wiped out gains made from the 2016-2017 drop in inflation. While the reduction in the rate of poverty due to inflation was similar in urban and rural areas, actual poverty increased substantially in urban areas, in part due to the continuing rural-urban migration trend which saw the rural population shrink by 2.7 million people and the urban population grow by 5.8 million (World Bank, 2018).

\footnotetext{
${ }^{1}$ Individual's names are pseudonyms
} 
Riski, an activist working in Banten province commented, in July 2017, on the rural-urban-international migration trend, and how this is affecting village life.

Every year our villages are getting smaller. Many young people do not see a future here, outside of farming. Young women look for jobs in Jakarta factory. In some villages this has led to labor shortage . . no one to work on farm, plant and harvest crops. Sometimes young women with baby goes to city for working. Now her mother must look after baby, so she cannot work. One more person added to urban population and 2 people removed from rural labor pool. The young woman may work in factory where illness and injury are common. Only the factory owner wins. This hurts everyone else. She thinks work abroad has more money and safer, so she go. (participant interview, Riski).

Indonesia's large labor surplus contributes to both its low-wage economy and the rise in subsistence level informal job activity. Although the unemployment rate has dropped over the years, from 8.1 percent in 2000 to $5.6 \%$ in 2016 (World Bank, 2018), the actual number of unemployed has increased over the years, from 50 million in 2000 to 70 million in 2016, and is forecast to increase further, to 77 million by 2019 (Trading Economics, 2018). The number of formal salaried jobs increases at a much slower pace than those in the informal sectors. While men, in August 2017 were employed at a rate of $78 \%$, employment for women was just $51 \%$, with almost no change for the past 25 years. Moreover, women earn $42 \%$ less than their male counterpart (Suzrez, 2018). Although wage gaps between men and women are higher in the informal sector, the difference is greater at the lower end of the informal sector. Efforts to improve gender equality through legislation have been unfruitful (Suzrez, 2018).

Should Riski decide to work as a domestic worker in Jakarta, rather than taking her chances with illness and injury in a factory, she would become a member of an officially unrecognized work force; domestic workers, unlike recognized laborers, receive no minimum wage protection and have no rights under national labor laws, in terms of minimum wage, acceptable hours of work and work duties. Participants report that domestic workers in Jakarta can expect to receive about Rp $300,000^{2}$ per month, work 16 hours per day and have no recourse should they become injured or sick on the job, or if employers do not pay or terminate their employment without notice. Activists at Indonesia untuk keadilan global (Indonesia for Global Justice), were interviewed in 2016 regarding the non-recognition of domestic work in Indonesia and the effect this situation has on pressuring women to migrate.

Indonesia for Global Justice, a non-governmental research institute located in Jakarta, studies Indonesia's foreign trade policy and bilateral trade and labor agreements. As an advocacy group for labor, it reviews migrant labor trends both nationally and internationally, advocating for policies beneficial to both formal and informal sector workers. Sam, a researcher for the institute, asserts that there are two reasons for the government's non-recognition of domestic work:

As a practical measure the government could never verify domestic employment in order to apply existing labor laws. There are thousands of women moving from job to job every couple of months. The government does not have the wherewithal to monitor them. Also, a fragmented itinerant work force cannot easily politicize government ineffectiveness in labor policy. Better to let them roam around the country aimlessly looking for work rather than help them organize. (participant interview, Sam)

Hari's experience in job hunting echoed Sam's thoughts regarding lack of employment protection. She commented on circumstances that led her to migrate to Saudi Arabia in 2003:

I left my family soon after Mille was born. Finding work in Jakarta is easy. . . but only for little money . . I could not even pay for enough food for myself . . could not send money to Fendi . . . air in factory very bad. No window to let in clean air. When I sick, factory no pay me and I have no money for food. Pay much better in Arabia so go there ... stay two years. Now I back but soon I go training center then Hong Kong for domestic job. (participant interview, Hari)

Indonesia for Global Justice unsuccessfully lobbied the Ministry of Manpower to enforce existing labor laws regarding factory work, and to establish guidelines of acceptable practice in terms of what constitutes domestic work, and to create an arbitration board or other mechanism whereby domestic workers can air grievances. Sam believes the Ministry's failure to recognize domestic work as a legitimate work sector, and to establish acceptable work conditions and wages, has left many women no option but migration, a situation that grew rapidly after the 1997 economic crisis and the fall of Suharto's "New Order". Collins (2007) believes that, after the crisis, the decision to restore the economy through debt led growth, was pivotal in the ensuing years of chaos.

$2300,000 \mathrm{IDR}=21 \mathrm{USD}$ 
For a few years the effects of the crisis were hidden thanks to heavy borrowing to finance make-work and infrastructure projects. When the country had absorbed as much debt as possible, politicians turned to selling natural resources, primarily lumber and minerals, causing environmental devastation. The Mega Rice Project (1996-1998) converted one million hectares of peatland to rice fields and in so doing, created $4000 \mathrm{~km}$ of drainage and irrigation channels. The roadways necessitated by this project opened up access to previously inaccessible timber resources. By 1997, 15 million square kilometers of South-East Asia was blanketed with yellow/grey toxic smog for weeks at a time, caused by burning peat swamp forests. Twenty percent of Kalimantan's peat swamp was destroyed in a period of a few years (Boehm \& Siegert, 2001). Because tropical rainforests grow on poor quality soil, in above average temperatures they do not revive quickly. "Tropical rainforests ... removed either by large scale cutting or by uncontrolled forest fires . . take centuries to revive" (Boehm \& Siegert, 2001, p. 2). This, in comparison to 10 to 30 years regeneration time for forests in more moderate climates with better soils.

While the peat lands and the rainforests were being systematically destroyed to make room for rice farming and to garner income from timber export, much of the small-scale subsistence family farming was degraded by heavy-metal runoff or flooding. At the same time Suharto opened the economy to foreign controlled factories in the suburban areas, drawing young adults off the farms and into lives of servitude; young men and women looking for escape from rural devastation found little respite in urban areas. Locke (2002) reports that Nike built a factory empire throughout Asia in the 1980s and 1990s, employing 25,000 workers in Indonesia at 6 factories in the 1990s, swelling to 30 factories and 104,000 factory workers by 2001, second only to China. Workers were underpaid, as Nike bargained successfully to be exempt from the daily wage of 1 U.S. dollar per day (Locke, 2002). Many young men eventually left the factories for Malaysian rubber plantations or for laboring work in the Middle-East; women turned to domestic servitude in Asia and the Middle East. It is widely acknowledged that government fiscal incompetence was aided by corruption on a vast scale (Olken, 2006, 2007; Robertson-Snape, 1999; Rodriguez, Uhlenbruck, \& Eden, 2005). Sumi, a volunteer for Indonesia for Global Justice commented on how fiscal mismanagement impacted the poor:

The situation for village people is that they cannot make a reasonable living in the villages. Once they decide to move into the wider economy, to look for better work, they become subject to more powerful forces, usually minor government officials who will prevent their success, unless those village people can offer something of value in return. We work for little pay in factories. Eventually many will contact a petugas lapangan ${ }^{3}$, or perhaps even a tai kong or calo $^{4}$ and look for work in other country. We should not be forced from our country for survival. We protest this exploitation. (participant interview, Sumi)

Even though there has been world-wide condemnation of rural environmental destruction continuing for decades (Alisjahbana \& Busch, 2017), and labor abuse since the beginning of the Suharto government such that "enforcement of labor law is highly imperfect, corruption is rampant, and government labor inspection is extraordinarily weak" (Bartley, 2010, p. 22), these twin spectra have continued to force both rural and urban poor from their homes, and into potentially perilous work situations abroad, sometimes never to resettle in their homeland. McCawley (2014), at the beginning of Joko Widodo's tenure as president, pointed out that Indonesia's poverty has been steadily declining over the past decade - but then the caveat: "But the official poverty line is a harsh measure of less than \$1 USD per day. If \$2 USD per day were used as the threshold, almost $50 \%$ of Indonesians would be classified as poor" (p. 13). More recently, since 2015, poverty has increased, though growth has been hovering around 5\%. Prices of the most basic foodstuffs have increased - rice by $16 \%$ in 2015 , and sugar by more than $13 \%$. Although in his campaign for president in 2014 Widodo was seen (and largely still is seen) as having a genuine desire to reduce poverty, in 2015 poverty increased from $11 \%$ to $11.2 \%$, putting another 900,000 people below that \$1USD a day threshold (Badan Pusat Statistik, 2015). On the environmental front there is hope that new ways of governing carbon emissions through the Reducing emissions from deforestation and forest degradation plus (REDD+) plan (Astuti \& McGregor, 2015), will result in long term environmental stability.

\subsection{Lack of Jobs Skills Training and Adult Education Opportunities}

Low education level has been shown conclusively to be an important predicator of poverty (Alisjahbana \& Yusuf, 2003; McKay \& Lawson, 2003). The World Bank has recommended that the Indonesian government adopt a comprehensive skills training strategy aimed at informal sector workers, the majority of whom have no access to skills training; a legacy from the 1999-2003 government planning strategies, which lacked robust skills training

\footnotetext{
${ }^{3}$ Labor broker usually working under contract for a licensed labor recruitment agency

${ }^{4}$ Informal labor broker, often of questionable legal repute
} 
components (World Bank, 2010). In an attempt to rectify training at high school level, in 2005 the government set out to increase vocational secondary schools, aiming to have $70 \%$ of students enrolled in public or private vocational schools by 2015 (World Bank, 2010). The program has been controversial in that it calls for the national government to reduce construction of academic secondary schools and convert a number of these into vocational schools. The lack of training in the sciences has been critical. By 2011 Indonesia ranked 52 out of 56 countries surveyed in the Trends of International Mathematics, Science Study (TIMMS) (Felestin \& Triyono, 2015). It had risen to $44^{\text {th }}$ place by 2015 (Gurney-Read, 2016). Unfortunately, this modest rise in TIMMS seems likely to result in a higher number of proficient but unemployed graduates as formal sector jobs are lacking.

The government has implemented numerous comprehensive educational programs including universal kindergarten, primary and secondary education, but adult literacy programs and skills training programs which focus on both urban and underdeveloped rural areas, have been much more limited. The United Nations Educational, Scientific and Cultural Organization (UNESCO) in its Education for All country report (UNESCO, 2000) cites Indonesia as having, since 1990, put education at the top of its development program, establishing formal education for young people as keystones in its drive. In particular, Indonesia has established 360 community education sites. Programs include secretarial training, hotel management, computer literacy, electronics, automotive mechanics, food preparation and fashion design. These supplement already existing training in fish farming, and animal husbandry. However, the report also notes that the economic collapse that led to currency devaluations and unemployment in 1997 were still being felt a decade later, and this has caused a large disparity between the number of job seekers and job opportunities which has possibly led to demotivation in those who might otherwise seek skills training. Nevertheless, the Ministry of Education recognizes the value of rural programs:

Community and religious leaders take the initiative by gladly becoming volunteers in AE program implementation. By this way there is no difficulty at all in mobilizing tutors, facilitators and cadres as the vanguard of AE programs and activities. The priority targets . . . are the poor families . . . those who are unemployed ... . with poor education . . . but not properly reached by the educational and skills development services (Ministry of Education and Culture, 2006).

The Ministry of Education goes on to describe, in positive terms, programs that should benefit villages such as those in rural Banten province. "The Ministry ... opens opportunities for participants who are able to pay off their first credit installment (in the training program for small farmers and fishermen), to obtain more loans and receive full assistance in marketing their products, while those who are still illiterate can join the literacy course" (p. 8). In fact, Indonesia contributed $20 \%$ of its budget in 2015 to kindergarten, primary and secondary education, and increased its educational spending 9 fold from 2001 to 2014 (World Bank, 2017). In Java, by 2015, 97\% of primary aged children attended school, as did $78 \%$ of junior secondary and $60 \%$ of secondary aged children. Unfortunately, the statistics for remote and poor areas were significantly weaker, largely due to other infrastructure issues such as lack of electricity: 21\% have access in Papua versus $99 \%$ in Java (World Bank, 2017).

Despite the positive comments above, migrants' rights activists, as well as villagers, felt that not enough was being done to provide useful job training skills at the village level. I interviewed Sring, a returned migrant and a neighbor of Fendi and Hari.

I just came back from Saudi Arabia. I been there 2 years. Before I been in Kuwait 2 years. No proper training for women in villages in Indonesia. Have training for men to work in fish farm. Have little training for men to be carpenter or machine shop worker. Before I leave no training for women. Now I return and no training for women. Government not helping any people in countryside, so we go Hong Kong, Singapore or other place (participant interview, Sring).

In 2010 the government did introduce a financial management workshop program for domestic workers going abroad. These were taught through recruitment agencies and consisted of a series of three 2-day workshops, covering practical skills for those migrating to Hong Kong, Taiwan, Singapore and the Middle East. Skills included banking, remittance, debt management, insurance and practical skills such as completing banking forms, opening bank accounts, and keeping a budget. The series of 3 workshops were held in Malang, East Java and attracted between 30 and 100 participants each. The workshops have developed into an ongoing series, monitored by The World Bank through surveys and interviews.

Despite the positive sounding momentum of government workshops, Sheena, the volunteer for SBMI, echoed Sring's skepticism concerning government motives:

These workshops are useful for women going abroad to work. The government has chosen to emphasize 
and support such employment as it brings the country foreign exchange. And these workshops are provided by recruitment agencies, the very companies that tell us that we must sacrifice our own desires, freedom and independence to the wishes of our employers in Hong Kong and Singapore. Organizations that train workers to be subservient cannot also give them the skills to be independent. It makes no sense. We need training to help us cope with work in Indonesia, so we do not have to leave. But at least at training centers ${ }^{5}$, women can receive basic instruction in how to operate common household machinery. Some village women have never used a common washing machine. Some have only been to Jakarta once or twice in their lives. They do not know how to use ATM machine because they do not have bank account. They do not know how to be safe in a big city. They can only get this training if they go abroad. That should not be the case. (participant interview, Sheena)

Fendi pointed out that assistance is needed in training villagers in both basic fish farming methods as well as more advanced hatchery and aquaculture methods. But beyond that, most villagers do not understand principals of marketing. Fendi suggested that, given inter-village market competitiveness, villagers should acquire more sophisticated marketing strategies. Although there are government sponsored training programs, they are usually only available in larger centers that require travel and lodging. Despite the Ministry of Education's assertations above, education authorities failed to provide training that could have a direct bearing on village income. The government training system, according to Fendi, does not function as it should. "If these programs worked, people could see a future in fishing . . . they would stay in the village . . . there would be less migration." (participant interview, Fendi)

Sheena felt that community education programs were difficult to access by most and tend to ignore suggestions from villagers regarding training needs.

The actual situation is that everything comes from the provincial authorities. People [villagers] have control over only minor programs or some small courses. This [Ministry of Education program] should be a life transforming opportunity but fails to address actual needs. National mechanisms for community education have been in place for years but local directorate offices reward on a political basis not on the basis of actual need (participant interview, Sheena).

Indonesia Direktorat Fendidikan Masyarakat (The Directorate of Community Education or PENMAS), is the department within the Ministry of Education and Culture responsible for community education. Villagers believe PENMAS is reluctant to host sustained training in poorer remote areas, believing it more cost effective for people from such areas to work abroad. During a focus group meeting, community members indicated that most villagers had only primary school education because the high school is some distance away and the resulting journey would be beyond the financial means of most. Villagers felt that if a permanent secondary school could not be built then it might be possible to create a mobile unit which could provide services to remote villages. As Fendi pointed out:

Everything too expensive. School costs are 25,000 rupiah each day. Traveling together by bus each student must pay 15,000 rupiah. Food and small things cost another 10,000. This is more than most families can afford. Ministry say we too small to have high school. We must only fish. But income from fishing very small. If we want high school learning, must travel to Serang ${ }^{6}$. If you do not live in a big town than your expenses are higher. We would like the government to help with extra expenses, but always they say no money (participant interview, Fendi).

Fendi spoke about the work abroad option:

For women, she go to training center 3 months or 1 year, then Arabia, Hong Kong or Singapore. She become maid in home. Many of these jobs terrible. She feel lonely and miss kids. For man, more difficult to work abroad. If mechanic, ok. If have a skill, ok. Otherwise cutting cane or working on rubber plantation in Malaysia. But easier for women get job abroad (participant interview, Fendi).

Returned migrants, reflecting on their previous educational experience, also recognized that lack of educational opportunity in villages was a prime motivating factor forcing them into migration. Rini, a 22-year old domestic worker who recently returned from a 4-year sojourn in Singapore and Hong Kong, indicated that there was no chance of more than basic primary education while she was at home:

\footnotetext{
${ }^{5}$ Training centers are almost exclusively occupied by women, receiving training as domestic workers. Time in training centers ranges from several weeks to approximately one year. Conditions vary from abhorrent to reasonable. Government monitoring of the conditions is weak.

${ }^{6}$ The provincial capital.
} 
Farming is all we do. My father go to school for 4 years. My mother never go to school. My brothers and sisters stopped school after a few years to help fishing. I had to migrate or get married . . . no chance for more school. I think, what about my future? Will I be poor all my life? Why can't I have education and learn skill? I probably go abroad again because no choice. But domestic work make me sad. No good future for me (participant interview, Rini).

Lani, another returned migrant also commented about lack of access to post-primary education:

When younger I want to learn more and study more . . not possible . . . no secondary school. I didn't want to get married then [so I] went to Singapore then Hong Kong. My mother wanted me to get married [so] I had to go home. In Javanese life we [women] have three things, masak ${ }^{7}$, manak $^{8}$ and macak $^{9}$. Soon I will get married and do these things (participant interview, Lani).

Fendi and Hari's house and furnishings were clearly among the nicest in the village. The house included a refrigerator, a large color TV, and new kitchen cabinets, tables and chairs. Fendi unwrapped a new blanket for the floor space on which I slept. Typically, homes from which family members have migrated are conspicuous for their good maintenance and relative abundance of consumer items. Although Fendi made an income from fishing, and as village secretary, the prime family income had been derived from Hari's overseas employment. She will stay with her husband and daughter for another year or two but will almost certainly seek work abroad again. Hari asserted that "it is very hard to make money in the villages . . . I will have to leave to help my family again" (participant interview, Hari).

Although PENMAS, under the leadership of the Ministry of Education and Culture created a system - two decades ago - that is meant to provide bottom up input into community development and education, participants indicated that major educational decisions are made at the provincial government level, with no significant input coming from village members. Furthermore, the allocation of funds appears to be politicized, with money going to those villages that support provincial policies. Lack of educational and vocational training opportunities heavily influenced migration decisions, but also influenced migrants to remain abroad longer, often returning home because of family pressures to marry.

\subsection{Life Experience, Empowerment and Satisfaction}

Zelinsky (1971) believes that as societies develop there is a tendency toward systems internationalization and that only the most parochial of systems are exempt from this tendency. Changes in economic systems, industrialization, and socio-cultural liberalization engender a desire for personal freedom and empowerment. Fawcett (1989), expanding on internationalization as a factor in migration decision making, examines mass cultural connections such as international media, print, movies and television. He believes that such media may work in favor of, or against, migration decision making, depending upon community expectations for young people, and media-relayed attitudes toward potential migrants in destination locations. And although Fawcett wrote when the internet was in its infancy, the popularity of immediately accessible desire creation tools, would factor into his migration conceptual framework.

Several participants described a desire to leave the traditional bounds of their community in the hopes that this would lead to empowerment and the satisfaction they believed would come with new life experiences away from the confines of family and village life. Titi, who had been in Hong Kong for four years, and studied English on Sundays, wrote in her class journal:

My mother working her bisnis selling palm leaf to restaurant. Restaurant wrap rice and meat and hot sauce in banana leafs and sell. Father living home but no work. I marry and move to town. Have one kid 8 years old. Everyone say my husband like my father. He no work, have girlfriend next door, I hate him very much. Mother say I go back work in her bisnis. I no want. I go Singapore 2 years. After I go Hong Kong 4 years. I want make my own life how I like. My future not in Indonesia. Now send money build house and money for kid. That is my duty. (participant journal, Titi).

Because Titi missed her daughter, she contemplated leaving Hong Kong and returning home. However, she felt that, despite her desire to be at home, she could be of more financial benefit in Hong Kong. In addition, she envisioned continual disputes with her husband concerning his relationship with a neighbor, someone whom she had known since childhood. Thus, in August 2017 she signed a new contract, committing herself to another two

\footnotetext{
${ }^{7}$ cooking

8 giving birth

9 applying makeup
} 
years in Hong Kong.

According to DeJong, Chamratrithirong and Tran (2002), European Union governments have included life-satisfaction as a "basic national performance indicator along with economic performance, employment, and economic competitiveness" (p. 841). Life-satisfaction and migration are theoretically linked, according to Ziegler and Britton (1981) in that "people migrate to become better off, in some subjective sense" (p. 304). In Titi's situation, although she had to leave her child in the care of her mother, she felt a sense of justification - of doing her familial duty in providing a home for her daughter. Her personal reward was found in a sense of freedom from a complicated family situation and a sense of emancipation.

Disputes with family members also contributed to Yule's decision to migrate. Just prior to completing a two-year sojourn in Hong Kong, Yule, a volunteer English teacher at Koalisi Tengara Kerja Indonesia di Hong Kong (Coalition of Indonesian Migrant Workers Association Hong Kong), explained her reasons for leaving home, as well as her reasons for returning sooner than planned. She indicated that her father had abandoned the family in 2007 when she was 16 years old, an act which caused her to "hate" him. Afterwards she, her younger brother and her mother continually argued and fought. During one particularly heated argument her brother wounded her father with a kitchen knife. Because of family tension she decided to migrate and hopefully start a new life.

I really could not live at home any more. I felt crushed. No matter what I did someone complained. My mother did not like my boyfriend, my brother did not like any of my friends. Sometimes I see my father in the village and it make me very angry and sad together. I need to get away to live my own life (participant journal, Yule)

Yule and I worked together, team-teaching English language speaking and writing skills every Sunday for several years. When the Canadian Montessori Association opened a training center in the Hong Kong YMCA, she, along with two other volunteers, left KOTKIHO (due to conflicting schedules) to enroll in their program. After graduation she moved to Jogjakarta where she now teaches in a Montessori Center.

Yule like Titi was facing an almost overwhelmingly negative family situation - a need that could only be met by leaving home and village. She was able to further enhance her migration experience through education. Research (Fernandez-Ballesteros, 2001) indicates that life satisfaction is both directly and indirectly linked with income and education. Direct links include increased access to higher quality housing and food, along with higher potential job satisfaction. Indirect links include social prestige and familial recognition as someone to be admired and respected. Similarly, Cheung and Chan (2009) found that "education seems to be the strongest predictor of life satisfaction across the 35 countries [where research was conducted]" (p. 332). But education is only one route to life satisfaction.

Resa, an undocumented Indonesian domestic worker, was motivated by a desire to escape the confines of Banyuwangi, a small city close to Bali. She had travelled to Bali several times after turning 18 and enjoyed the international flavor of the bars and discos. Resa indicated that her home life was good but "boring". Finally, she decided to seek work in Hong Kong. After finishing her first two-year contract she overstayed her visa and became an undocumented worker. She would occasionally return to Banyuwangi to visit family but preferred a more cosmopolitan atmosphere and would remain in Hong Kong as long as possible. In 2012 she wrote:

Hong Kong is an exciting city. I have no regular employer so spend lot of time playing with friends. I work enough for my expenses. Just as part-time domestic, that is enough for me. But I afraid this will not last long. Someday must return home to live. (participant journal, Resa)

In 2017 anecdotal information suggested that Resa had an Australian boyfriend, and later that year married and migrated to Australia. Diner and Suh (1997) found that the link between personal freedom and happiness is unclear. Where personal freedom results in perceived success, there is a positive correlation. However, when personal freedom does not lead to success there are often fewer social and familial supports, resulting in unhappiness. Resa enjoyed a lifestyle of freedom in Hong Kong and was actively searching for ways not to settle down in Indonesia. It appears that she was able to realize that desire.

\section{Discussion, Recommendations and Conclusion}

Recent literature contends that the current increasing level of migration from Indonesia is largely the consequence of political and economic decisions made from the early 1980s through the 1990s. Although the economy was improving in the late 1990s, it could not withstand the devaluation of the rupiah, thereby plunging lower income workers into poverty. The economic situation under the current government has improved, with a stronger and more stable rupiah. Still, migration continues to increase.

This study finds that economic decisions negatively impacted rural adult's abilities to access skills training, and 
where individuals were able to access training, this usually did not result in employment as there were few jobs available in rural areas. The resulting rural-urban migration pushed unskilled workers into factory work with pay at, and often below, the poverty line. Thus, migration abroad became the only financially viable option. Unfortunately, under the current government, little has changed in this regard. Although the government has prioritized education, it has done little to improve the situation of adults who live in rural areas and cannot travel to larger centers for vocational training. Participants were not provided with satisfactory explanations for the lack of mobile training units that might improve their access to training. Adult skills training has received only moderate increases in funding, and much of this has been attached to migrant training centers. Migrants argue that providing training at such centers is indicative of the governments priorities - foreign remittances rather than educational commitments. Migrant activists believe the government does not actively promote worker associations that might exert influence on employers as these are not welcomed by factory owners. Monitoring needs to be conducted by independent worker organizations, with real power to affect change, unencumbered by political bias. Although most participants consider migration a temporary economic solution, some viewed it as, not only a way out of poverty, but a foothold into what they hoped would be a new and prosperous life. For many, however, the solution to unemployment at home has developed into chronic inter-generational chain migration.

Further research needs to be conducted to evaluate the impact of the Widodo government's economic policies, in light of the continued rise in migration. The link between life satisfaction and the decision to migrate also requires further study. Although migrants report a desire to experience life outside the bounds of the immediate family and village, it is unclear how socio-cultural liberalization, and infiltration by outside cultures - often indirectly through popular social media, factors into the migration decision.

\subsection{Limitations}

Several limitations impact this study. Firstly, migration rates are not compared with those of other Asian countries. Such a comparison might better situate the Indonesian migration experience. Secondly, although the purpose of this study is not to generate statistics, but to provide a medium for personal migrant experiences through a 'snowball' data collection method, statistical data collection and analysis may provide a complementary and wider view of migration trends.

\section{References}

Alisjahbana, A., \& Busch, J. (2017). Forestry, forest fires, and climate change in Indonesia. Bulletin of Indonesian Economic Studies, 53(2), 111-136. https://doi.org/10.1080/00074918.2017.1365404

Alisjahbana, A., \& Yusuf, A. A. (2003). Poverty dynamics in Indonesia: Panel data evidence. Working Papers in Economics and Development Studies.

Amin, S. (2003a). Confronting the empire. Monthly Review, 55(3), 15-22. https://doi.org/10.14452/MR-055-03-2003-07_2

Amin, S. (2003b). World poverty, pauperization, \& capital accumulation. Monthly Review, 55(5), 1-9. https://doi.org/10.14452/MR-055-05-2003-09_1

Astuti, R., \& McGregor, A. (2015). Governing carbon, transforming forest politics: A case study of Indonesia's REDD+ Task Force. Asia Pacific Viewpoint, 56(1), 21-36. https://doi.org/10.1111/apv.12087

Badan Pusat Statistik. (2015). Pertumbuhan ekonomi Indonesia triwulan II-2015. Retrieved from http://www.bps.go.id/website/brs_ind/brsInd-20150805111616.pdf

Bartley, T. (2010). Transnational private regulation in practice: The limits of forest and labor standards certification in Indonesia. Business and Politics, 12(3). https://doi.org/10.2202/1469-3569.1321

Battistella, G., \& Asis, M. (1999). The crisis and migration in Asia. Quezon City: Scalabrini Migration Center.

Benish-Weisman, M. (2009). Between trauma and redemption: Story form differences in immigrant narratives of successful and nonsuccessful immigration. Journal of Cross-Cultural Psychology, 40(6), 953-968. https://doi.org/10.1177/0022022109346956

Boehm, H., \& Siegert, F. (2001). Ecological impact of the one million hectare rice project in central Kalimantan, Indonesia, using remote sensing and GIS: Land use change and (il)-legal logging in Central Kalimantan, Indonesia. Paper presented at the 22nd Asian Conference on Remote Sensing, Singapore.

Brante, E. (2012). Stand together or fall alone: Narratives from former teachers. Narrative Works: Issues, Investigations \& Interventions, 2(2), 20-40.

Bury, M. (2001). Illness narratives: Fact or fiction? Sociology of Health \& Illness, 23(3), 263-285. 
https://doi.org/10.1111/1467-9566.00252

Cheung, H., \& Chan, A. (2009). The effect of education on life satisfaction across countries. The Alberta Journal of Educational Research, 55(1), 124-136.

Citizens' Network on Essential Services. (2003). Water and the future of the social contract. Retrieved from $\mathrm{http} / / / \mathrm{www}$. servicesforall.org/html/water/water_social_contract.html

Clough, P. (2002). Narratives and fictions in educational research. Buckingham: Open University Press.

Clough, P. (2004). Frank. In D. Goodley, R. Lawthom, P. Clough, \& M. Moore (Eds.), Researching life stories: Method, theory and analyses in a biographical age (pp. 40-52). London: RoutledgeFalmer.

Collins, E. C. (2007). Indonesia betrayed: How development fails. Honolulu: University of Hawaii Press.

DeJong, G., Chamratrithirong, A., \& Tran, Q. (2002). For better: For worse. Life satisfaction consequences of migration. The International Migration Review, 36(3), 838-863.

Denzin, N. K. (1989). Qualitative Research Methods. New York: Sage.

Diener, E., \& Suh, E. (1997). Measuring quality of life: Economic, social, and subjective indicators. Social Indicators Research, 40, 189-216. https://doi.org/10.1023/A:1006859511756

Fawcett, J. (1989). Networks, linkages and migration systems. International Migration Review, 23(3), 671-680. https://doi.org/10.2307/2546434

Felestin, F., \& Triyono, M. B. (2015). The implementation of total quality management at vocational high schools in Indonesia. 2015, 1(1), 12. https://doi.org/10.21831/reid.v1i1.4895

Fernandez-Ballesteros, R. (2001). The contribution of socio-demographic and psychosocial factors to life satisfaction. Ageing and Society, 21, 25-43. https://doi.org/10.1017/S0144686XX1008078

Friends of the Earth. (2007). Indonesia: Privatization of Jakarta water utilities. Retrieved from https://www.foei.org/news/world-bank-water-projects-in-asia

Gonzalez-Lopez. (2015). Men's life stories Family secrets: Stories of incest and sexual violence in Mexico (pp. 180-231). New York: NYU Press.

Gray, D. (2001). Accommodation, resistance and transcendence: Three naratives of autism. Social Science \& Medicine, 53, 1247-1257. https://doi.org/10.1016/S0277-9536(00)00424-X

Gurney-Read, J. (2016, November 29). Revealed: World pupil rankings in science and maths - TIMSS results in full. The Telegraph. Retrieved from http://www.telegraph.co.uk/education/2016/11/29/revealed-worldpupil-rankings-science-maths-timss-results/

Harrison, A., \& Scorse, J. (2003). Globalization's impact on compliance with labor standards. Bookings Trade Forum, 45-96. https://doi.org/10.1353/btf.2004.0010

Hill, H. (1999). The Indonesian economy in crisis: Causes, consequences and lessons. Singapore: Institute of Southeast Asian Studies.

Kessler, T. (2003). Services for all. Paper presented at the Workshop on the Privatization of Basic Services, Washington, D.C.

Klots, Y. (2011). The ultimate city: New York in Russian immigrant narratives. The Slavic and East European Journal, 55(1), 38-57.

Locke, R. M. (2002). The promise and perils of globalization: The case of Nike. Retrieved from Cambridge: https://ipc.mit.edu/sites/default/files/documents/02-007.pdf

Martyn, H. L. (2018). Narratives as catalysts for transformation and social action planning within the Hong Kong Indonesian migrant community. Asian Social Science, 14(6), 106-117. https://doi.org/10.5539/ass.v14n6p106

McCawley, P. (2014). Strategy: Joko Widodo's Indonesia: Possible future paths. Retrieved from https://core.ac.uk/download/pdf/30673675.pdf

McKay, A., \& Lawson, D. (2003). Assessing the extent and nature of chronic poverty in low income countries: Issues and evidence. World Development, 31(3), 425-439. https://doi.org/10.1016/S0305-750X(02)00221-8

Ministry of Education and Culture. (2006). Government of Indonesia.

Morris, D. (2017). Varieties of erotic experience: Five illness narratives. In D. Morris (Ed.), Eros and Illness (pp. 
107-134). Harvard University Press.

Murray, H. (2010). Not in this family: Gays and the meaning of kinship in postwar North America. University of Pennsylvania Press.

Olken, B. (2006). Corruption and the costs of redistribution: Micro evidence from Indonesia. Journal of Public Economics, 90(4), 853-870. https://doi.org/10.1016/j.jpubeco.2005.05.004

Olken, B. (2007). Monitoring Corruption: Evidence from a Field Experiment in Indonesia. Journal of Political Economy, 115(2), 200-249. https://doi.org/10.1086/517935

Polkinghorne, D. (1995). Narrative configuration in qualitative analysis. International Journal of Qualitative Studies in Education, 8(1), 5-23. https://doi.org/10.1080/0951839950080103

Riessman, C. K. (2015). Ruptures and sutures: time, audience and identity in an illness narrative. Sociology of Health \& Illness, 37(7), 1055-1071. https://doi.org/10.1111/1467-9566.12281

Robertson-Snape, F. (1999). Corruption, collusion and nepotism in Indonesia. Third World Quarterly, 20(3), 589-602. https://doi.org/10.1080/01436599913703

Rodriguez, P., Uhlenbruck, K., \& Eden, L. (2005). Government corruption and the entry strategies of multinationals. Academy of Management Review, 30(2). https://doi.org/10.5465/amr.2005.16387894

Roy, J. (1997). Letter from Jakarta. SAIS Review, 17(2), 77-92. https://doi.org/10.1353/sais.1997.0038

Suzrez, C. (2018). Gender inequality in Indonesia's labor market. Retrieved from https://phys.org/news/2016-02-gender-inequality-indonesia-labour.html

Tambunan, M. (1998). Economic reforms and agricultural development in Indonesia. ASEAN Economic Bulletin., 15(1). https://doi.org/10.1355/AE15-1D

Tjandraningsih, I. (2000). Gendered work and labour control: Women factory workers in Indonesia. Asian Studies Review, 24(2), 257-268. https://doi.org/10.1080/10357820008713273

Trading Economics. (2018). Indonesia unemployed persons: 1980 to 2018. Retrieved from https://radingeconomics.com/indonesia/unemployed-persons

UNESCO. (2000). Indonesia country report. Country reports. Retrieved from http://planipolis.iiep.unesco.org/en/2000/efa-2000-assessment-country-report-indonesia-3791

Van Dijk, K. (2001). A country in despair: Indonesia between 1997 and 2000. Leiden: KITLV Press.

World Bank. (1995). Self-provision of water and power: Costly responses to public failure. Development Brief Number 55. Retrieved from http://documents.worldbank.org/curated/en/191721468292247686/Self-provi sion-of-water-and-power-costly-responses-to-public-failure

World Bank. (2010). Indonesia jobs report: Towards better jobs and security for all. Retrieved from https://openknowledge.worldbank.org/handle/10986/27901

World Bank. (2017). Towards a comprehensive, integrated, and effective social assistance system in Indonesia. Retrieved from http://documents.worldbank.org/curated/en/535721509957076661/pdf/120905-REVISEDPUBLIC-Screen-English-1211-update.pdf

World Bank. (2018). Towards inclusive growth. Retrieved from http:/www.worldbank.org/en/country/indonesia/publication/indonesia-economic-quarterly-march-2018

Young, K. (2004). Globalisation and the changing management of migrating service workers in the Asia Pacific. Journal of Contemporary Asia, 34(3), 287-303. https://doi.org/10.1080/00472330480000111

Zelinsky, W. (1971). The hypothesis of mobility transition. Geographical Review, 62(1), $219-249$. https://doi.org/10.2307/213996

Ziegler, J., \& Britton, C. (1981). A comparative analysis of socioeconomic variations in measuring the quality of life. Social Science Quarterly, 62(303-312).

\section{Copyrights}

Copyright for this article is retained by the author(s), with first publication rights granted to the journal.

This is an open-access article distributed under the terms and conditions of the Creative Commons Attribution license (http://creativecommons.org/licenses/by/4.0/). 